\title{
Analysis of Physical Education for Special College Students
}

\author{
Jun Huang \\ Physical Education Department, Southwest University of Science and Technology, Mianyang, \\ 621010, China
}

Keywords: special students, physical education, teaching methods

\begin{abstract}
With the development of China's college education, lots of injured, disabled, weak, sick and old etc students study in colleges and thus become special students. With a variety of objective factors, these special students cannot adapt to normal college physical education. Thus, with respect to actual situation of special college students, new physical education teaching methods shall be studied and explored to enhance physical quality of special college students and promote their comprehensive development. This paper mainly introduces the current situation of physical education for special college students, analyzes problems in such education, and puts forward corresponding solutions etc.
\end{abstract}

\section{Introduction}

Among college students, there are some special students with certain physical and mental defects, and thus are known as special students. They often need more care, and are one of important parts of college students, and shall enjoy the same rights with normal students. In college physical education, more attention shall be paid to special students, to enable them to enjoy fun in physical education, enhance their skills in physical education, strengthen their physical qualities, and promote their overall development.

\section{Current situation and problems of physical education for special students in Chinese colleges}

At present, there are some problems in physical education for special students in Chinese colleges, affecting teaching effects. These problems mainly include:

(1) Imperfect sports right legal system for special students

So far, China has not clear laws to regulate sports right, and such regulation is not implemented very well in some colleges. Although sports right of citizens has been mentioned in Sports Law and Regulations on the Education of the Disabled, there is not clear term for detailed declaration. This leads to a lack of right to carry out physical education for special college students. Firstly, this is reflected in a lack of right to know about physical education, namely special college students do not know about sports right they enjoy and thus fail to enjoy such right. This proves that the country and colleges have not enough publicity of sports right and knowledge education. Special students do not know about their sports right, reduce opportunities to participate in physical activities, and thus fail to improve physical qualities effectively. Secondly, special college students are greatly restricted in physical activities. Many special college students have mental and physical defects, which lead to great mental pressure in physical activities. They have physical inconvenience in physical exercise, and cannot complete corresponding physical actions, and worry about being discriminated or laughed at by students mentally. This will cause great harm to self-esteem and confidence of these students, and they will not participate in physical activities gradually and lose enthusiasm and interest in physical courses. Some students may even be afraid of physical education, and begin to escape and reject physical education. Moreover, physical education for special college students also lacks appropriate venues and devices, which greatly restricts participation of these students. Finally, many teachers and students have some wrong thoughts, believing that physical education is not greatly related to special students, and content, devices and performance of physical education are rights that normal students shall enjoy. Because of such a wrong understanding, few people are concerned about physical education learning condition of special students, while colleges fail to supervise and manage physical education learning condition 
of special students. As a result, physical education loses due effects for special students.

(2) Physical education is inconsistent with requirements of special students

There are two types of college students, namely normal ones and special ones. For these two types of students, different physical courses shall be applied. However, colleges generally apply the same course standards when carrying out physical education and treat all students equally, which seriously affect physical education effects for special students. So, when carrying out physical education, colleges shall take different teaching plans for different student groups, so that all of them could receive corresponding physical exercise and development. In physical education, normal students could strengthen physical training, while special students can only do some basic physical activities, improve their physical qualities and have strengthened physical training slowly. When designing teaching objectives, targeted design shall be made according to actual situation of special students to ensure effects of physical education.

(3) Physical teaching materials do not apply for special students

In physical education, Chinese colleges have almost the same choices without difference between normal students and special students. As a result, special students cannot adapt to teaching materials. Therefore, teaching materials become a difficulty in physical education for special students, and would not apply for special students if fail to meet their actual needs, which will seriously affect teaching quality. So, in physical education for special students, problems of teaching materials shall be solved and appropriate teaching materials shall be selected according to actual situation of special students, in order to enhance teaching effects.

(4) Physical education teachers cannot meet demands of special students

Physical education for special students has very high requirements for physical education teachers, namely rich basic knowledge about physical education, good physical qualities, extremely strong sports ability and ability to help physical training of special students. More importantly, physical education teachers shall have good morality, and shall be concerned about special students, be enthusiastic in classes, have a correct teaching concept, help each special student, teach each student carefully and help students be confident. However, in Chinese college physical education, physical education teachers for special students shall be further enhanced by strengthening their professional skills, having a correct understanding and helping each special student patiently.

(5) Backward concept of physical education

In many Chinese colleges, special students lack enough understanding of physical education and rarely participate in physical activities, which violate people-oriented teaching concept in this era. Although many colleges have accepted special students, training quality of special students is doubted, and colleges rarely consider about issues from the perspective of special students. Such backward concepts seriously affect teaching effects and quality of special students.

\section{Causes of problems in physical education for special students}

Currently, there are many problems in education for special students in Chinese colleges, affecting teaching quality. These problems are generated mainly by the following causes.

(1) College leaders do not pay enough importance

In physical education for special college students, importance that leaders attach determines teaching effects and quality. Work can be supervised and guided only when importance is attached to, and effects and quality of this work can be promoted. In many Chinese colleges, there is neither special physical education course nor physical activities for special groups. Although some colleges have set up some physical courses for special students, leaders fail to attach enough importance, which leads to absence of sound rules and regulations for physical education for special students, formal and arbitrary physical education. As a result, due effects and quality cannot be obtained.

(2) Imperfect course system

In education, teaching effects of any courses require a sound course system to ensure teaching quality. However, in Chinese colleges, the number of special students increases constantly, but there is not a scientific course system. Physical course system is generally for ordinary students instead of special ones. Many colleges have great randomness in physical course system for special students 
without teaching objectives, content and corresponding devices, and lack targeted teaching. All these seriously affect teaching effects of special students.

(3) Insufficient teachers for special students

Due to particularity of special students, colleges have not enough physical education teachers. Compared with physical education teachers for normal students, those for special students shall have more physical education knowledge as well as health care and rehabilitation skills. However, in today's colleges, physical education teachers for normal students also teach special students, and there are few professional physical education teachers for special students, coupled with few training and practice. All these result in limited level of physical education teachers for special students, and thus teaching effects are affected.

(4) Lack of special venues and facilities

Venues and facilities are guarantee of teaching effects of physical education for special students. However, when carrying out physical education for special students, many colleges lack appropriate sports venues and facilities for special students. Importance that leaders attach and college funds lead to seriously insufficient venues and facilities for physical education for special students, and many colleges have not venues and facilities for those students. Due to lack of appropriate hard facilities, special students are not enthusiastic for physical activities, and thus it is difficult to enhance physical teaching effects.

\section{Reform strategy of physical education for special college students in China}

(1) Establish and perfect relevant laws and regulations

For special students, China shall establish and perfect relevant laws and regulations with targets and applicability from the perspective of those students to perfect college physical education system, so that each special student could know about their rights, enhance their interest in physical exercise gradually, and thus improve teaching effects.

(2) Reform of teaching content and methods

Teaching content is the basis of teaching quality. So, physical education for special students shall be based on actual situation of students, respect students, select appropriate physical teaching content, and enhance students' enthusiasm for participating in physical activities by different methods. Firstly, classified management can be carried out according to characteristics of special students, so as to use different teaching content and methods when teaching. Secondly, carry out differentiated teaching according to actual situation of students. Each student has his/her characteristics. Particularly, special students have great differences. Thus, different physical teaching resources shall be used for differentiated teaching according to students' characteristics, interests, ability and needs. Such teaching will have better effects than collective teaching, as it organizes special students to have differentiated learning according to their actual conditions and characteristics, which can not only enhance students' mental feelings, but also stimulate students to participate in physical activities actively, enhance their enthusiasm for physical education and teaching effects.

(3) Strengthen building of physical education teachers for special students

Teachers determine effects of physical education, and are the most important part of physical education. So, in physical education for special students, colleges shall strengthen teachers building, allocate teacher-student ratio reasonably, introduce professional physical education teachers for special students, and provide education trainings for all physical education teachers in order to enhance their professional qualities constantly. In addition, colleges shall also establish a supporting system according to actual situation of special students, set physical exercise instructor and volunteer system for special students, and help them have physical exercise. This could not only share pressure of physical education teachers for special college students, but also increase opportunities to contact with special students, know about difficulties of special students in life and learning, stimulate and guide students to overcome and deal with difficulties, strengthen physical exercise constantly, improve their physical quality, and enhance a sense of achievement and confidence. 
(4) Perfect sports venues and devices for special students

Colleges shall spare no efforts in providing a material foundation for special students, and thus ensure effects and quality of physical education, and perfect sports venues and devices for special students. College leaders shall attach importance to physical education for special students, and invest funds in perfecting relevant devices and equipment, which could meet the use of both normal and special students, increase these students' interest in physical exercise, enhance their enthusiasm for physical exercise and thus promote the quality of physical teaching.

\section{Conclusions}

Each citizen in the society enjoys equal right to receive education, so do special students. Thus, colleges shall strengthen care and education for special students, solve difficulties of these students in learning and life, and improve their learning environment and educational quality. College physical education shall pay full attention to learning effects of special students, cultivate their awareness of lifelong physical exercise, guide and encourage them to participate in physical activities actively, enhance physical quality and promote overall enhancement of comprehensive qualities.

\section{References}

[1] Tao Jinyu. Exploratory Study on College Physical Education Course Setting [J]. The Youth Writers. 2011 (05).

[2] Guan Yue. Study on Participation of Physically Vulnerable Groups in Shanghai Colleges in Physical Activities [D]. Shanghai University of Sport. 2010.

[3] Han Jingjun, Wang Yue. How to Carry out Physical Education for Mentally Retarded Students in Special Schools in Dandong [J]. Journal of Liaodong University (Natural Sciences). 2010 (03).

[4] Zhu Wenjie. Study on Development of College Special Physical Course Resources [J]. Inner Mongolia Sports Science and Technology. 2011 (03).

[5] Li Kaiyong. On Physical Disability of Special Adolescents and Educational Countermeasures [J]. Anhui Literature (Second Half). 2010 (11).

[6] Liu Hui, Liu Lijiang, Tang Jun, Li Yuejuan. Investigation and Analysis of Influencing Factors of Disabled College Students' Participation in Jiangxi Province in Physical Exercise and Development Countermeasures [J]. Journal of Chifeng College (Natural Science Edition). 2012 (11).

[7] Liu Chaojian. Analysis of Current Situation of Weak Groups in College Physical Education and Countermeasures-A Case Study of Ma'anshan City in Anhui Province [J]. Science \& Technology Information. 2010 (12).

[8] Hong Banghui. Study on Current Situation of Physical Education in Guizhou Special Education Schools and Development Strategies [D]. Guizhou Normal University. 2009. 